\title{
Rumen characteristics and feed utilization in goats fed with biologically treated oil palm fronds as roughage in a total mixed ration
}

\author{
P. Chanjula ${ }^{1 \#}$, V. Petcharat ${ }^{2}$ \& A. Cherdthong ${ }^{3}$ \\ ${ }^{1}$ Department of Animal Science, Faculty of Natural Resources, Prince of Songkla University, Hat Yai Campus, \\ Songkhla 90110, Thailand \\ ${ }^{2}$ Department of Pest Management, Faculty of Natural Resources, Prince of Songkla University, Hat Yai Campus, \\ Songkhla 90110, Thailand \\ ${ }^{3}$ Tropical Feed Resources Research and Development Centre (TROFREC), Department of Animal Science, \\ Faculty of Agriculture, Khon Kaen University, KhonKaen 40002, Thailand
}

(Received 15 September 2017; Accepted 16 July 2018; First published online 8 December 2018)

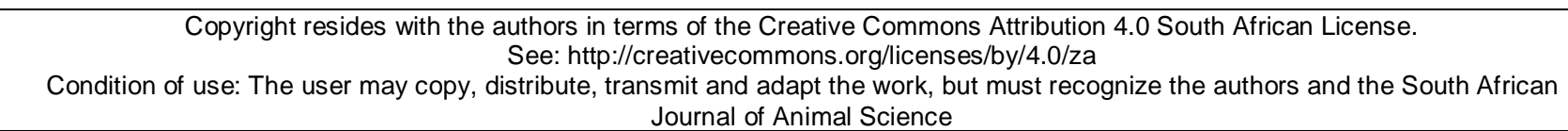

\begin{abstract}
Six male crossbred (Thai Native $\times$ Anglo Nubian) goats, $33.5 \pm 1.7 \mathrm{~kg}$ body weight (BW), were randomly assigned to a $3 \times 3$ replicated Latin square design to investigate the effects of fungal-treated oil palm fronds (FTOPF) on feed intake, digestibility, ruminal fermentation and nitrogen utilization. The treatments were untreated oil palm frond (UOPF; T1), fungal treated oil palm frond (FTOPF; T2) and fungal treated oil palm frond with urea 1\% (FTOPFU; T3). The results revealed that voluntary feed intake was not significantly different among treatments, while digestion coefficients of nutrients (DM, OM, CP, NDF, and ADF) increased significantly with FTOPF. However, the mean ruminal temperature, $\mathrm{pH}, \mathrm{NH}_{3}-\mathrm{N}$, blood ureanitrogen and amount of $\mathrm{N}$ absorbed and retained were similar among treatments. In conclusion, FTOPF could be included in total mixed rations without any adverse effect on feed intake, digestibility and rumen fermentation efficiency, suggesting that FTOPF could be used potential as an alternative roughage source for ruminants.
\end{abstract}

Keywords: Agricultural by-product, digestibility, fungal treatment, Lentinussajor-caju, small ruminant \# Corresponding author: pin.c@psu.ac.th

\section{Introduction}

The increasing expansion of the oil palm industry over the past few years all over the world has led to the accumulation of agricultural by-products such as leaves and petioles, called oil palm fronds (OPF) (Rahman et al., 2011). The utilization of OPF, a cheap and abundant by-product of the oil palm industry, has received particular attention lately in many tropical countries, such as Indonesia, Malaysia and Thailand, owing to its potential to be utilized as a roughage source or a component in complete diets for ruminants (Zahari \& Alimon, 2005).

However, the use of OPF in livestock production is limited owing to its complex fibre structure and poor metabolisable energy value (4.9 - 5.6 MJ metabolisable energy [ME]/kg dry matter (DM)) (Ishida \& Abu Hassan, 1997; Zahari \& Alimon, 2005), as well as the fact that lignin constitutes $20 \%-20.5 \%$ of its dry biomass (Abdul Khalil et al., 2006). Lignin can be considered as an anti-nutritional factor, limiting feed digestibility. In order to break down the lignocellulosic bonds and increase bioavailability of nutrients, various physical and chemical delignification methods have been examined in agricultural by-products such as in rice and wheat straws (Hamed \& Elimam, 2010; Shah et al., 2017a;b). However, those methods are expensive, have a low effectiveness and are not environmentally friendly. The possibility of biological methods of treating roughages, e.g. using white rot fungi (WRF) (Jalc et al., 1996) to improve its quality, has great appeal as an alternative to the use of corrosive and polluting chemicals. Additionally, colonization with WRF is considered to be a promising technique because of its preferential degradation of lignin (Moyson \& Verachtert 1991; Okano et al., 2009). In addition, improving the utilization of low quality roughages could be 
achieved through their treatment with nitrogen $(\mathrm{N})$ sources. Wanapat (2000) reported that urea-treated rice straw could increase overall intake and digestibility, which thus resulted in enhancing the performance of ruminants as compared to untreated rice straw. Therefore, this study was conducted to investigate the effect of fungal treated oil palm fronds without or with urea on feed intake, digestibility, ruminal fermentation and $\mathrm{N}$ utilization in goats.

\section{Materials and Methods}

The trials were conducted at the Department of Animal Science, the Faculty of Natural Resources, Prince of Songkla University (PSU), Hat Yai Campus. All procedures involving animals in the metabolism and finishing studies were approved by the Institutional Animal Care and Use Committee, Prince of Songkla University (Ref. no. IACUCPSU 48/2017), based on the Ethical of Animal Experimentation of National Research Council of Thailand (NRCT).

A Lentinussajor-caju strain, provided by the Biotechnology Research and Development Office, Department of Agriculture, Thanyaburi, PathumThani 12110 Thailand, was used to inoculate oil palm fronds (OPF). The OPF was provided by the Faculty of Natural Resources, Prince of Songkla University, Hat Yai Campus, Songkhla 90110, Thailand. The preparation of fungal treated oil palm frond (FTOPF) was briefly as follows: Fresh OPF was chopped into pieces, 1 - $2 \mathrm{~cm}$ in length, and air dried at ambient temperature (30 $\left.35^{\circ} \mathrm{C}\right)$, was packed in plastic bags $\left(30 \times 45 \mathrm{~cm}\right.$ ) and autoclaved at $100-102{ }^{\circ} \mathrm{C}$ for $2 \mathrm{~h}$ and then cooled down at room temperature $\left(28-32{ }^{\circ} \mathrm{C}\right)$. The autoclaved OPF were inoculated with sorghum grain spawns of Lentinussajor-caju cultures at a rate of $4 \% \mathrm{w} / \mathrm{w}$ (fresh weight basis) and re-packed in plastic bags. The culture bags were transferred to a fermentation room and incubated for 21 days at room temperature for full colonization of the mushroom mycelia on the substrate. After 21 days of incubation, all bags were removed from the fermentation room and the OPF substrates were sun-dried for 3 - 5 days (Fazaeli et al., 2004). The air-dried spent OPF was packed in plastic bags $(45 \times 90 \mathrm{~cm})$ and stored at room temperature pending the investigation.

Six crossbred (Thai Native $x$ Anglo Nubian) male goats, 18 months old with an average body weight (BW) of $33.5 \pm 1.7 \mathrm{~kg}$, were randomly assigned to the dietary treatments in a $3 \times 3$ replicated Latin square design. The treatments were: untreated oil palm frond (UOPF; T1), fungal treated oil palm frond (FTOPF; T2) and fungal treated oil palm frond with $1 \%$ urea (FTOPFU; T3). All OPF were included in total mixed diets at a $30 \%$ inclusion rate (Table 1). The diets were formulated to provide the nutrient allowances to meet or exceed the NRC (1981) requirements of growing goats. All goats were kept in individual pens $(0.115 \times 0.95$ $\mathrm{m})$ under well-ventilated sheds where water and mineral block were available at all times. Mineral block (10 $\mathrm{kg}$ ) containing $5 \%$ phosphorus, $5 \%$ magnesium, $3.7 \%$ calcium and $20 \%$ sodium $20 \%$, as well as all the essential trace elements necessary for the goats, such as iodine (600 mg), selenium (50 mg), copper (3 500 $\mathrm{mg})$, cobalt $(100 \mathrm{mg})$, zinc $(3000 \mathrm{mg})$ and manganese $(1000 \mathrm{mg})$ were provided. The experiment was conducted for 3 periods and each period lasted for 21 days. During the first 14 days of each period, all animals were fed the respective diets ad libitum and during the last 7 days the animals were moved to metabolism crates for total tract digestibility studies. Feed was provided twice daily in two equal portions at 08:00 and 16:00. Feed offered and refusals were collected and weighed daily before feeding for daily dry matter intake (DMI) determinations over the last 7 days.

Feed samples were collected during the last 7 days of each period and composited by period on an equal weight basis for further analysis. Urine and faecal samples were collected using the total collection method from each individual goat during the last 7 days of each period and composited per goat. Feed and faecal samples were oven-dried at $60^{\circ} \mathrm{C}$ for $72 \mathrm{~h}$, ground to pass through 1-mm sieve screen using Cyclotech Mill, Tecator, and analysed for DM, ether extract (EE), ash, crude protein (CP) levels (AOAC, 1995), and acid detergent fibre (ADF) and neutral detergent fibre (NDF) levels (Van Soest et al., 1991). Nonstructural carbohydrate (\% in the DM) was calculated as:

100 - moisture (\%) - crude protein (\%) - ether extract (\%) - neutral detergent fibre - ash (\%).

Urine samples were analysed for urinary $\mathrm{N}$ using the Kjeldahl procedure described by the AOAC (1995) for calculation of $\mathrm{N}$ utilization.

At the end of each period, ruminal fluid was collected from each goat by using a stomach tube at $4 \mathrm{~h}$ post feeding. Fluid samples were strained through 4 layers of cheese cloth, and temperature and $\mathrm{pH}$ were measured immediately, using a pH meter (HANNA instruminalts $\mathrm{HI} 98153$ microcomputer $\mathrm{pH}$ meter, Singapore) fitted with a combined electrode. The rumen fluid of $30 \mathrm{~mL}$ was then acidified with $3 \mathrm{~mL}$ of $1 \mathrm{M}$ $\mathrm{H}_{2} \mathrm{SO}_{4}$. The mixture was centrifuged at $16000 \times g$ for $15 \mathrm{~min}$, and the supernatant was stored at $-20{ }^{\circ} \mathrm{C}$ for ammonia nitrogen $\left(\mathrm{NH}_{3}-\mathrm{N}\right)$ analysis using the micro-Kjeldahl methods (AOAC, 1995) and volatile fatty acid (VFA) analysis by using HPLC (Samuel et al., 1997). Blood samples (about $10 \mathrm{~mL}$ ) were collected from a 
jugular vein (at the same time as ruminal fluid sampling) into tubes containing $12 \mathrm{mg}$ of EDTA, and plasma was separated by centrifugation at $2500 \times \mathrm{g}$ for $15 \mathrm{~min}$ at $5^{\circ} \mathrm{C}$ and stored at $-20^{\circ} \mathrm{C}$ until analysis for blood urea nitrogen (BUN) according to the method of Crocker (1967). On the last day of each period, the goats were moved from the metabolism crates to their individual pens for the adaptation of the next diet period for 14 days.

All data obtained from the experiment were subjected to ANOVA for a $3 \times 3$ replicated Latin square design by using the GLM procedure (SAS Inst. Inc., Cary, NC). Data were analysed using the model:

$$
Y_{\mathrm{ijkl}}=\mu+S_{1}+A_{i(l)}+P_{j}+T_{k}+\varepsilon_{i j k l ;}
$$

where: $Y_{i j k l}$ observation from animal $i(I)$, receiving diet $k$, in period $j$;

$\mu$, the overall of mean,

$S_{1}$, the effect of square,

$A_{i}$, the effect of animal $(i=1,2,3)$,

$P_{j}$, the effect of period $(j=1,2,3)$,

$T_{k}$, the mean effect of treatment $(k=1,2,3)$, and

$\varepsilon_{i j k l}$, the residual effect.

Treatment means were statistically compared using Duncan's Multiple Range Test (Steel \& Torrie, 1980) to identify differences between means.

\section{Results and Discussion}

The feed ingredients and chemical composition of the experimental diets are presented in Table 1. The UOPF source contained high fibre levels. However, fungal treatment of OPF with/without urea (before mixed into diet) decreased NDF, ADF and ADL when compared to control group. The lower NDF and ADF levels following fungal treatment might be an indication of cell wall breakdown due to Lentinussajor-caju. Generally, NDF and ADF ( 3 and 9 wks colonization) levels of OPF decreased when colonized with WRF (Rahman et al., 2011). Similarly, decreases in the levels of these fibre fractions were also reported by Jalc et al. (1996) and Fazaeli et al. (2006) for wheat straw colonized for 2 - 4 wks with $P$. ostreatus, madake bamboo colonized for 10 wks with $C$. subvermispora (Okano et al., 2009), OPF colonized for 3 - 9 wks with C. subvermispora (3 wks) and L. edodes and P. brevispora (9 wks) (Rahman et al., 2011). The above results thus suggest that fungal fermentation improved the nutritive value of the straw by lowering its cell wall content. It has been widely reported that high ADF and/or lignin levels result in a low digestibility of feed (Vadiveloo et al., 2009; Sarnklong et al., 2010; Shah et al., 2017a; b), especially the lignified cell walls because of a low fermentation rate and digestibility, which lead to a low rate of disappearance through digestion or passage, and thus limited feed intake. Structural modification of cell wall components due to the respective urea or fungal treatment appears to facilitate fibre-degrading microbes in the rumen to degrade fibrous components more intensively, therefore increasing the digestibility of the feed (Wanapat, 2000).

Table 2 shows that the overall means of total intakes of DM, OM, NDF and ADF of each goat were not affected by dietary treatments, while CP intake tended to increase in goats that were fed FTOPF and FTOPFU $(P=0.07)$. On the other hand, total tract digestibility of DM, OM, CP, NDF, ADF and ADL were significantly $(P<0.05)$ increased in goats receiving FTOPF or FTOPFU. The higher nutrient digestibility of the treated OPF diet might be explained by the lower NDF, ADF and ADL levels compared with UOPF. These results are supported by Fazaeli et al. (2002), who reported that nutrient digestibility of fungal-treated wheat straw diet was equal to that of the alfalfa diet when it constituted up to $30 \%$ of the diet of lactating cows. Similar to the present results, Fazaeli et al. (2004) found that total tract digestibility of DM, OM and gross energy were increased in bulls fed fungal-treated wheat straw. This was also found by Kafilzadeh et al. (2009), who investigated sheep consuming Pleurotusflorida-treated date palm leaves. Similarly, Mahesh et al. (2013) found that feeding wheat straw supplemented with Crinipellis sp. to Sahiwan calves resulted in an increase in the nutrient digestibility, and it was concluded that solid state fermentation with Crinipellis sp. has the potential to upgrade the nutritive value of wheat straw.

The effect of fungal treatment of OPF on the patterns of ruminal fermentation is given in Table 3 . The ruminal $\mathrm{pH}$ and temperature ranged from 6.48 to 6.53 and 39.2 to $39.3{ }^{\circ} \mathrm{C}$, respectively, and were not significantly different among treatments, and the values were within the optimum range for cellulolytic bacteria activity (Cherdthong et al., 2011) and digestion of protein $(\mathrm{pH}=6.0-7.0)$. A high $\mathrm{pH}$ is favourable for bacterial adherence, an important prerequisite for fibre digestion (Simon et al., 2005; Palmonari et al., 2010), while a pH < 6.1 could inhibit cellulolysis (Wanapat, 2000). Similarly, $\mathrm{NH}_{3}-\mathrm{N}(19.52-21.43 \mathrm{mg} / \mathrm{dL})$ and BUN (17.69 - $20.65 \mathrm{mg} / \mathrm{dL}$ ) concentration were similar among treatments and were in an optimal range 
Table 1 Ingredient proportion and chemical composition of the experimental diets, oil palm frond (OPF), and fungal treated oil palm frond (FTOPF) (\% DM basis)

\begin{tabular}{|c|c|c|c|c|c|c|}
\hline \multirow{2}{*}{ Item } & \multicolumn{3}{|c|}{ Dietary treatments ${ }^{1}$} & \multirow{2}{*}{ UOPF } & \multirow{2}{*}{ FTOPF } & \multirow{2}{*}{ FTOPFU } \\
\hline & UOPF & FTOPF & FTOPFU & & & \\
\hline \multicolumn{7}{|l|}{ Ingredients, \% } \\
\hline UOPF & 30.0 & - & - & & & \\
\hline FTOPF & - & 30.0 & - & & & \\
\hline FTOPFU & - & - & 30.0 & & & \\
\hline Ground corn, GC & 45.0 & 45.0 & 45.0 & & & \\
\hline Soybean meal, SBM (44\% CP) & 7.3 & 7.3 & 7.3 & & & \\
\hline Fish meal, 55\% CP & 0.4 & 0.4 & 0.4 & & & \\
\hline Leucaena leave meal, LLM & 7.0 & 7.0 & 7.0 & & & \\
\hline Palm kernel cake, PKC & 7.0 & 7.0 & 7.0 & & & \\
\hline Molasses & 2.1 & 2.1 & 2.1 & & & \\
\hline Dicalcium phosphate & 0.4 & 0.4 & 0.4 & & & \\
\hline Salt & 0.2 & 0.2 & 0.2 & & & \\
\hline Mineral and vitamin mix & 0.7 & 0.7 & 0.7 & & & \\
\hline \multicolumn{7}{|c|}{ Analysed nutrient composition, $\%$ of dry matter } \\
\hline Dry matter & 95.3 & 95.2 & 94.9 & 52.4 & 50.8 & 50.5 \\
\hline Ash & 5.30 & 6.12 & 6.19 & 6.49 & 7.40 & 7.24 \\
\hline Organic matter & 94.7 & 93.9 & 93.8 & 93.5 & 92.6 & 92.8 \\
\hline Crude protein & 15.12 & 15.30 & 15.35 & 4.62 & 7.24 & 7.58 \\
\hline Ether extract & 3.98 & 3.83 & 3.42 & 1.99 & 1.87 & 1.89 \\
\hline Non-structural carbohydrate ${ }^{2}$ & 29.27 & 30.15 & 31.15 & 2.88 & 11.69 & 15.15 \\
\hline Neutral detergent fiber & 46.3 & 44.60 & 43.9 & 84.0 & 71.8 & 68.1 \\
\hline Acid detergent fiber & 25.3 & 24.8 & 23.2 & 70.1 & 57.4 & 56.6 \\
\hline Acid detergent lignin & 12.27 & 10.60 & 10.01 & 25.17 & 24.13 & 24.01 \\
\hline Hemicellulose $^{2}$ & 20.99 & 19.81 & 20.70 & 13.90 & 14.41 & 11.56 \\
\hline Cellulose $^{2}$ & 13.07 & 14.19 & 13.18 & 44.95 & 33.26 & 32.57 \\
\hline
\end{tabular}

${ }^{1}$ UOPF $=$ untreated oil palm frond, FTOPF = fungal treated oil palm frond, FTOPFU = fungal treated oil palm frond with $1 \%$ urea

${ }^{2}$ Calculated values; Non-structural carbohydrate was calculated as: 100 - moisture (\%) - crude protein (\%) - ether extract (\%) - neutral detergent fibre - ash (\%); Hemicellulose= neutral detergent fibre- acid detergent fibre

Cellulose $=$ acid detergent fibre-lignin

$>5 \mathrm{mg} / \mathrm{dL}$ for microbial protein synthesis (Satter \& Slyter, 1974) and 10 to $20 \mathrm{mg} / \mathrm{dL}$ for optimum degradation of fibrous feed (Preston \& Leng, 1987). According to Erdman et al. (1986), maximum DM digestion of low and high degradability feed occurred at ruminal ammonia concentrations of 170 and $250 \mathrm{mg} / \mathrm{L}$, respectively. The higher rumen $\mathrm{NH}_{3}-\mathrm{N}$ concentration in the FTOPFU treatment was due to urea being the supplemental source of N. Meanwhile, BUN concentration was similar among treatments, ranging from 17.69 to 20.65 $\mathrm{mg} / \mathrm{dL}$. It was close to the optimal level in normal goats, which had been reported in the range of 11.2 to 27.7 $\mathrm{mg} / \mathrm{dL}$ (Lloyd, 1982).

There were no differences among treatments in total ruminal VFA concentration, molar proportions of acetate $\left(\mathrm{C}_{2}\right)$, propionate $\left(\mathrm{C}_{3}\right)$, butyrate $\left(\mathrm{C}_{4}\right)$ other VFAs (isobutyrate, isovalerate, valerate and caproate), and the ratio of acetate to propionate $(A: P)$. However, total VFA concentration tended to increase at $4.3 \mathrm{mmol} / \mathrm{L}$ for goats that were fed FTOPF as compared with UOPF $(P=0.09)$. Karunanandaa \& Varga (1996) found that a fungal (Cyathus stercoreus) treated rice straw diet increased total VFAs and proportion of $\mathrm{C}_{3}$ and 
Table 2 Effects of diet on feed intake and nutrient digestibility of goats

\begin{tabular}{|c|c|c|c|c|c|c|}
\hline \multirow{2}{*}{ Intake measurements } & \multicolumn{3}{|c|}{ Dietary treatments ${ }^{1}$} & \multirow{2}{*}{ SEM } & \multicolumn{2}{|c|}{ Contrast, $P$-value ${ }^{2}$} \\
\hline & UOPF & FTOPF & FTOPFU & & T1 vs. FT & T2 vs. T3 \\
\hline \multicolumn{7}{|l|}{ Dry matter intake $(\mathrm{kg} / \mathrm{d})$} \\
\hline Total dry matter intake, $\mathrm{kg} / \mathrm{d}$ & 0.992 & 1.051 & 1.095 & 0.10 & 0.38 & 0.66 \\
\hline Dry matter intake, \%BW & 2.98 & 3.14 & 3.33 & 0.18 & 0.18 & 0.37 \\
\hline Dry matter intake, $\mathrm{g} / \mathrm{kg} \mathrm{W}^{0.75}$ & 71.69 & 75.64 & 79.79 & 5.28 & 0.22 & 0.45 \\
\hline Organic matter intake, kg/d & 0.930 & 0.984 & 1.053 & 0.09 & 0.28 & 0.46 \\
\hline Crude protein intake, $\mathrm{kg} / \mathrm{d}$ & 0.153 & 0.171 & 0.191 & 0.02 & 0.07 & 0.22 \\
\hline Neutral detergent fibre intake, $\mathrm{kg} / \mathrm{d}$ & 0.462 & 0.476 & 0.507 & 0.04 & 0.44 & 0.49 \\
\hline Acid detergent fibre intake, $\mathrm{kg} / \mathrm{d}$ & 0.246 & 0.253 & 0.260 & 0.02 & 0.60 & 0.77 \\
\hline \multicolumn{7}{|l|}{ Apparent digestibility, \% } \\
\hline Dry matter & $69.3^{b}$ & $73.1^{a}$ & $72.2^{\mathrm{a}}$ & 0.39 & 0.03 & 0.58 \\
\hline Ash & 49.0 & 50.7 & 49.7 & 0.64 & 0.21 & 0.38 \\
\hline Organic matter & $70.7^{b}$ & $74.6^{\mathrm{a}}$ & $73.7^{\mathrm{a}}$ & 0.39 & 0.04 & 0.58 \\
\hline Crude protein & $73.5^{\mathrm{b}}$ & $77.5^{\mathrm{a}}$ & $78.2^{\mathrm{a}}$ & 0.80 & 0.01 & 0.64 \\
\hline Ether extract & $74.1^{b}$ & $78.3^{\mathrm{a}}$ & $77.1^{\mathrm{a}}$ & 0.33 & 0.05 & 0.52 \\
\hline Neutral detergent fibre & $56.6^{b}$ & $64.7^{\mathrm{a}}$ & $62.5^{a}$ & 1.31 & 0.02 & 0.43 \\
\hline Acid detergent fibre & $35.8^{b}$ & $43.5^{a}$ & $40.8^{a}$ & 1.05 & 0.05 & 0.41 \\
\hline Acid detergent lignin & $23.5^{b}$ & $27.7^{\mathrm{a}}$ & $29.3^{\mathrm{a}}$ & 0.94 & 0.38 & 0.80 \\
\hline
\end{tabular}

${ }^{a-b}$ Means within rows followed with different superscript letters are statistically different $(P<0.05)$.

${ }^{1} \mathrm{FT}=$ Fungal treated. UOPF $=$ untreated oil palm frond, FTOPF $=$ fungal treated oil palm frond, FTOPFU $=$ fungal treated oil palm frond with $1 \%$ urea.

${ }^{2}$ Compares the effects of UOPF with the combined FT treatment.

Table 3 Effects of diet on rumen fermentation characteristics of goats

\begin{tabular}{|c|c|c|c|c|c|c|}
\hline \multirow{2}{*}{ Item } & \multicolumn{3}{|c|}{ Dietary treatments ${ }^{1}$} & \multirow{2}{*}{ SEM } & \multicolumn{2}{|c|}{ Contrast, $P$-value ${ }^{2}$} \\
\hline & UOPF & FTOPF & FTOPFU & & T1 vs. FT & T2 vs. T3 \\
\hline Ruminal pH & 6.53 & 6.51 & 6.48 & 0.06 & 0.72 & 0.70 \\
\hline Temperature, ${ }^{\circ} \mathrm{C}$ & 39.2 & 39.3 & 39.2 & 0.25 & 0.78 & 0.63 \\
\hline Ammonia-nitrogen, mg/dL & 19.5 & 19.8 & 21.4 & 0.36 & 0.49 & 0.81 \\
\hline Blood urea-nitrogen, mg/dL & 17.7 & 20.3 & 20.7 & 1.63 & 0.58 & 0.95 \\
\hline Total volatile fatty acids, $\mathrm{mmol} / \mathrm{L}$ & 74.9 & 79.2 & 74.1 & 1.34 & 0.09 & 0.11 \\
\hline \multicolumn{7}{|c|}{ Proportion of individual volatile fatty acids, \% } \\
\hline Acetate $\left(\mathrm{C}_{2}\right)$ & 71.7 & 70.4 & 71.9 & 0.57 & 0.53 & 0.21 \\
\hline Propionate $\left(\mathrm{C}_{3}\right)$ & 19.2 & 21.0 & 19.2 & 0.54 & 0.31 & 0.15 \\
\hline Butyrate $\left(\mathrm{C}_{4}\right)$ & 6.76 & 6.33 & 6.49 & 0.40 & 0.55 & 0.80 \\
\hline Other volatile fatty acids ${ }^{3}$ & 2.37 & 2.30 & 2.39 & 0.02 & 0.47 & 0.11 \\
\hline Acetate:propionate ratio & 3.78 & 3.39 & 3.76 & 0.13 & 0.32 & 0.17 \\
\hline
\end{tabular}

${ }^{\text {a-b }}$ Means within rows followed with different superscript letters are statistically different $(P<0.05)$.

${ }^{1} \mathrm{FT}=$ Fungal treated. UOPF $=$ untreated oil palm frond, FTOPF = fungal treated oil palm frond, FTOPFU = fungal treated oil palm frond with $1 \%$ urea.

${ }^{2}$ Compares the effects of UOPF with the combined FT treatment.

${ }^{3}$ Sum of isobutyrate, isovalerate, valerate and caproate. 
$\mathrm{C}_{4}$. In another study, Tripathi et al. (2008) found that bio-processed mustard straw with C. versicolor (21 days) increased rumen $\mathrm{pH}$ and total VFAs in sheep after $6 \mathrm{~h}$ of feeding. In this study, the total VFA concentration ranging from 70 to $130 \mathrm{mM}$ was similar to the finding of Hungate (1966) and France \& Siddons (1993). However, total VFA concentration in the rumen depends on factors such as digestibility, rate of absorption, rumen $\mathrm{pH}$, rate of passage from rumen to other parts of the digestive tract, as well as the microbial population in the rumen and their activities (Hungate, 1966). In addition, concentrations of branched-chain VFAs (isobutyrate and isovalerate) and valerate of the rumens of the goats were not adversely affected by dietary treatments.

Table 4 illustrates the effect of treated OPF on $\mathrm{N}$ utilization in goats. Total $\mathrm{N}$ intake and total $\mathrm{N}$ excretion in terms of faecal and urinary $\mathrm{N}$ were similar $(P>0.05)$ among treatments. However, total $\mathrm{N}$ intake of goats that received treated OPF tended to be higher than that of the control group $(P=0.08)$, which could be due to the higher DMI in the treated OPF $\left(4-8 \mathrm{~g} / \mathrm{kg} \mathrm{W}^{0.75}\right)$ groups compared with UOPF. This pattern of faecal and urine excretion is indicative of the extremely high $\mathrm{N}$ intake for goats fed diets containing $\mathrm{FT}$. Additionally, Cronje (1992) found that inadequate energy reduced the percentage of $\mathrm{N}$ retention in goats fed adequate levels of protein, and $\mathrm{N}$ recycling increased as the supply of energy increased. Likewise, the amount of $\mathrm{N}$ absorbed was increased through feeding treated OPF $(P=0.03)$, while $\mathrm{N}$ retention did not changed among treatments $(P>0.05)$. It was postulated that the greater $\mathrm{N}$ absorption was related to higher water-soluble carbohydrates (WSC) and lower fibre concentration in the treated OPF group. Okano et al. (2009) reported that cellulose, hemicelluloses and lignin are the main sources of carbon and energy for the growth of white-rot fungi. Therefore, mycelial proliferation by all the Lentinussajor-caju on OPF was possibly due to their saprophytic ability to solubilize structural carbohydrates and their ability to extract fibre bound $\mathrm{N}$ for their metabolism and growth (Jalc et al., 1996). The results provide little evidence that an increase in the synchrony between energy and $\mathrm{N}$ release in the rumen, which may be achieved by feeding treated OPF of higher WSC concentration, would improve microbial protein synthesis in the rumen. Hence, the positive $\mathrm{N}$ balance observed in the present study indicates that all diets supplied sufficient $\mathrm{N}$ to the goats.

Table 4 Effects of diet on nitrogen $(\mathrm{N})$ balance of goats

\begin{tabular}{|c|c|c|c|c|c|c|}
\hline \multirow{2}{*}{ Nitrogen balance } & \multicolumn{3}{|c|}{ Dietary treatments ${ }^{1}$} & \multirow{2}{*}{ SEM } & \multicolumn{2}{|c|}{ Contrast, $P$-value ${ }^{2}$} \\
\hline & UOPF & FTOPF & FTOPFU & & T1 vs. FT & T2 vs. T3 \\
\hline Total $N$ intake, g/d & 24.6 & 27.3 & 30.6 & 2.50 & 0.08 & 0.22 \\
\hline \multicolumn{7}{|l|}{ N excretion, g/d } \\
\hline Faecal N & 6.50 & 6.13 & 6.69 & 0.64 & 0.87 & 0.42 \\
\hline Urinary $\mathrm{N}$ & 4.65 & 4.53 & 5.34 & 1.39 & 0.84 & 0.64 \\
\hline Total N excretion & 11.15 & 10.66 & 12.03 & 1.23 & 0.88 & 0.39 \\
\hline Absorbed N & 18.08 & 21.19 & 23.90 & 1.95 & 0.03 & 0.20 \\
\hline Retained N & 13.43 & 16.66 & 18.32 & 2.30 & 0.11 & 0.54 \\
\hline
\end{tabular}

${ }^{a-b}$ Means within rows followed with different superscript letters are statistically different $(P<0.05)$.

${ }^{1} \mathrm{FT}=$ Fungal treated. UOPF = untreated oil palm frond, FTOPF = fungal treated oil palm frond, FTOPFU = fungal treated oil palm frond with $1 \%$ urea

${ }^{2}$ Compares the effects of UOPF with the combined FT treatment

\section{Conclusion}

Based on this investigation, fungal treatment of OPF has no effect on feed intake, ruminal fermentation patterns and $\mathrm{N}$ balance of goats, but it improved the digestion coefficients of nutrients. It is suggested that FTOPF could be effectively used as a roughage source in total mixed rations. However, further research and long-term studies on the feeding and the economics should be conducted to validate the effects of fungal-treated OPF in the performance of finishing goats in terms of both meat and milk.

\section{Acknowledgments}

The authors would like to express their most sincere gratitude and appreciation to the Department of Animal Science, Faculty of Natural Resources, Prince of Songkla University for financial support of this research (Project no. 
NAT570154B). This work was also supported by Increase Production Efficiency and Meat Quality of Native Beef and Buffalo Research Group, Khon Kaen University and the Thailand Research Fund (TRF) contract grant IRG5980010.

\section{Authors' Contributions}

PC conducted experiment, analysed data and wrote the manuscript. VP edited the manuscript. AC edited the manuscript. All authors read and approved manuscript.

\section{Conflict of Interest Declaration}

The authors declare that there is no conflict of interest.

\section{References}

Abdul Khalil, H.P.S., SitiAlwani, M. \& Mohd Omar, A.K., 2006. Chemical composition, anatomy, lignin distribution, and cell wall structure of Malaysian plant waste fibres. Biores. 1, 220-232.

AOAC, 1995. Official Methods of Analysis. $16^{\text {th }}$ ed. Assoc. Off. Anal. Chem., Arlington, VA., USA.

Cherdthong. A., Wanapat, M. \& Wachirapakorn, C., 2011. Influence of urea-calcium mixtures as rumen slow-release feed on in vitro fermentation using gas production technique. Arch. Anim. Nutr. 65, 242-254.

Crocker, C.L., 1967. Rapid determination of urea nitrogen in serum or plasma without deproteinzation. Am. J. Med. Technol. 33, 361-365.

Cronje, P.B., 1992. Differences in nitrogen and urea metabolism between goats bred for fibre production (Angora goat) or meat production (Boer goat). S. Afr. J. Anim. Sci. 22,143-148.

Erdman. R.A., Proctor, G.H. \& Vandersall, J.H., 1986. Effect of ruminal ammonia concentration on in situ rate and extent of digestion of feedstuffs. J. Dairy Sci. 69, 2312-2320.

Fazaeli, H., Jelan, Z.A., Mahmodzadeh, H., Liang, J.B., Azizi, A. \& Osman, A., 2002. Effect of fungal treated wheat straw on the diet of lactating cows. Asian-Australas. J. Anim. Sci. 11, 1573-1578.

Fazaeli, H., Mahmodzadeh, H., Azizi, A., Jelan, Z.A., Liang, J.B., Rouzbehan, Y. \& Osman, A., 2004. Nutritive value of wheat straw treated with Pleurotus fungi. Asian-Australas. J. Anim. Sci. 17, 1681-1688.

Fazaeli, H., Azizi, A. \& Amile, M., 2006. Nutritive value index of treated wheat straw with Pleurotus fungi fed to sheep. Pak. J. Bio. Sci. 9, 2444-2449.

France, J. \& Siddons, R.C., 1993. Volatile fatty acid production. In: Quantitive Aspects Ruminant Digestion and Metabolism. (Ed. J.M. Forbes and J. France). CAB International, Willingford, UK. pp. 107-122.

Ghorai, S., Banik, S.P., Verma, D., Chowdhury, S., Mukherjee, S. \& Khowala, S., 2009. Fungal biotechnology in food and feed processing. Food Res. Int. 42, 577-587.

Hamed, A.H.M. \& Elimam, M.E., 2010. Performance and digestibility in Nubian goats fed stream treated sorghum stover. Pak. J. Nutr. 9, 298-301.

Hungate, R.E., 1966. The Rumen and its Microbe. Academic Press, New York. NY. p. 533.

Ishida, M. \& Abu Hassan, O., 1997. Utilization of oil palm frond as cattle feed. Japan Agric. Res. Quart. 31, 41-47.

Jalc, D., Nerud, F., Zitnan, R. \& Sikora, P., 1996. The effect of white-rot basidiomyctes on chemical composition and in vitro digestibility of wheat straw. Folia. Microbiol. 41, 73-75.

Kafilzadeh, F., Hozhabri, F. \& Kabirifard, A., 2009. Effect of Pleurotusflorida on in vitro gas production of wheat stubble and date palm leaf. Res. J. Biol. Sci. 4, 37-41.

Karunanandaa, K. \& Varga, G.A., 1996. Colonization of rice straw by white-rot fungi (Cyathusstercoreus): Effect on ruminal fermentation pattern, nitrogen metabolism, and fiber utilization during continuous culture. Anim. Feed Sci. Technol. 61, 1-16.

Lloyd, S., 1982. Blood characteristics and the nutrition of ruminants. Br. Vet. J. 138, 70-85.

Mahesh, M.S., Mohini, M., Jha, P., Sawant, S.P., Kundu, S.S. \& Kuhad, R.C., 2013. Nutritional evaluation of wheat straw treated with Crinipellis sp. in Sahiwal calves. Trop. Anim. Health Prod. 45, 1817-1823.

Moyson, E. \& Verachtert, H., 1991. Growth of higher fungi on wheat straw and their impact on the digestibility of substrate. J. Appl. Microb. Biotechnol. 36, 421-424.

NRC, 1981. Nutrient Requirements of Goats: Angora, Dairy and Meat Goats in Temperate and Tropical Countries. National Academy Press, Washington, DC., USA.

Okano, K., Ohkoshi, N., Nishiyama, A., Usagaw, T. \& Kitagawa, M., 2009. Improving the nutritive value of madake bamboo, phyllostachysbambusoides, for ruminants by culturing the white rot fungus Ceriporiopsissubvermispora. Anim. Feed Sci. Technol. 152, 278-285.

Palmonari, A., Stevenson, D.M., Mertens, D.R., Cruywagen, C.W. \& Weimer, P.J., 2010. pH dynamics and bacterial community composition in the rumen of lactating dairy cows. J. Dairy Sci. 93, 279-287.

Preston, T.R. \& Leng, R.A., 1987. Matching ruminant production systems with available resources in the tropics and subtropics. Penambul Books, Armidale, New South Wales, Australia.

Rahman, M.M., Lourenço, M., Hassim, H.A, Baars, J.J.P., Sonnenberg, A.S.M., Cone, J.W., De Boever, J. \& Fievez, V., 2011. Improving ruminal degradability of oil palm fronds using white rot fungi. Anim. Feed Sci. Technol. 169, 157-166.

Samuel, M., Sagathewan, S., Thomas, J. \& Mathen, G., 1997. An HPLC method for estimation of volatile fatty acids of ruminal fluid. Indian J. Anim. Sci. 67, 805-807.

Sarnklong, C., Coneja, J.W., Pellikaan, W. \& Hendriks, W.H., 2010. Utilization of rice straw and different treatments to improve its feed value for ruminants: A review. Asian-Australas. J. Anim. Sci. 23, 680-692.

Satter, L.D. \& Slyter, L.L., 1974. Effect of ammonia concentration on rumen microbial protein production in vitro. Br. J. Nutr. 32, 199-208. 
Shah, A.A., Xianjun, Y., Zhihao, D., Junfeng, L. \& Sao, T., 2017a. Microbiological and chemical profiles of elephant grass inoculated with and without Lactobacillus plantarum and Pediococcus acidilactici. Arch. Microbiol. DOI:10.1007/s00203-017-1447-1.

Shah, A.A., Xianjun, Y., Zhihao, D., Siran, W. \& Tao, S., 2017b. Effects of lactic acid bacteria on ensiling characteristics, chemical composition and aerobic stability of king grass. J. Anim. Plant Sci. 27, 747-755.

Steel, R.G.D. \& Torrie, J.H., 1980. Principles and Procedures of Statistics: A Biometerial Approach. (2 ${ }^{\text {nd }}$ ed.). McGrawHill, New York, USA.

Stewart, C.S., 1977. Factors affecting the cellulolytic activity of rumen contents. Appl. Environ. Microbiol. 33, 497-502.

Tripathi, M.K., Mishra, A.S., Misra, A.K., Vaithiyanathan, S., Prasad, R. \& Jakhmola, R.C., 2008. Selection of white-rot basidiomycetes for bioconversion of mustard (Brassica compestris) straw under solid-state fermentation into energy substrate for rumen micro-organism. Lett. Appl. Microbiol. 46, 364-370.

Vadiveloo, J., Nurfariza, B. \& Fadel, J.G., 2009. Nutritional improvement of rice husks. Anim. Feed Sci. Technol. 151:299-305

Van Soest, P.J., Robertson, J.B. \& Lewis, B.A., 1991. Methods for dietary fiber, neutral detergent fiber, and nonstarch polysaccharides in relation to animal nutrition. J. Dairy Sci. 74, 3583-3597.

Wanapat, M., 2000. Rumen manipulation to increase the efficient use of local feed resources and productivity of ruminants in the tropics. Asian-Austral. J. Anim. Sci. 13 (Suppl. B), 59-67.

Zahari, M.W. \& Alimon, A.R., 2005. Use of palm kernel cake and oil palm by-products in compound feed. Palm Oil Developments, vol. 40. Malaysian Palm Oil Board, Kuala Lumpur, Malaysia. pp. 5-8. 